\title{
Using Discussion to Teach Capstone Courses in Psychology
}

\author{
Alyse M. Meadows, Michael Rose, Lawrence R. Burns, Katy Bellamy \\ Psychology Department, Grand Valley State University, Allendale Michigan, USA \\ Email: burnsl@gvsu.edu
}

How to cite this paper: Meadows, A. M., Rose, M., Burns, L. R., \& Bellamy, K. (2021). Using Discussion to Teach Capstone Courses in Psychology. Creative Education, 12, 122139.

https://doi.org/10.4236/ce.2021.121009

Received: September 22, 2020

Accepted: January 17, 2021

Published: January 20, 2021

Copyright (c) 2021 by author(s) and Scientific Research Publishing Inc. This work is licensed under the Creative Commons Attribution International License (CC BY 4.0).

http://creativecommons.org/licenses/by/4.0/

\begin{abstract}
The American Psychological Association (APA 2002, 2007, 2013) recommends the inclusion of a capstone course in psychology undergraduate teaching alongside traditional lecture-based learning. This review explores what is meant by a capstone course by taking a fresh look at empirically derived pedagogic theory and how this may address some long-standing curricular needs of the psychology faculty and undergraduate students. It then explores the use of Socratic teaching methods and how this could be used as a template for teaching a capstone course within psychology.
\end{abstract}

\section{Keywords}

Discussion-Based Class, Socratic Method, Capstone Courses, Pedagogic Theory

\section{Introduction}

According to the APA (2011), it is imperative that an undergraduate psychology program should give its students the opportunity to develop critical thinking skills; articulate and decisive communication; effective writing techniques; an ability to reason with numbers; and an aptitude for working with others who have diverse viewpoints, beliefs, mindsets, and talents (p. 10). The APA (2011) also suggests that a quality undergraduate psychology program includes an integrative capstone course that builds upon the foundations of the program and allows the exploration of the variability and cohesiveness of the psychological disciplines (p. 14). Originally, the Boyer Commission on Educating Undergraduates (1998) described how a capstone course should be organized. These objectives are summed up by Behrens (2005), in that a capstone course should:

1) bring together faculty and students in shared or mutually reinforcing projects; 
2) prepare undergraduates for both the expectations and standards of graduate work and the professional workplace;

3) broaden, deepen, and integrate the total experience of the major;

4) include a major project developed from previous research or internship experience;

5) allow for collaborative efforts among students.

However, the APA (2011: p. 14) and Behrens (2005) suggest there is a wide variety of how higher education institutions can define and achieve a capstone course. Some interpreted a capstone course as a literature review of psychology; another described its capstone course as a history of psychology; and finally, one institution depicted its capstone course as a session where students are asked to reflect on their future direction within the major. These findings suggest that senior psychology undergraduates are not being offered consistent capstone courses that deliver the goals initially described by the Boyer Commission (1998) nor the APA. The ambiguity of the definition of a capstone course, along with the rapidly changing pedagogical situation due to COVID-19, leaves the question of how to design a capstone course that is effective in creating psychology professionals who are prepared to enter the demanding, diverse world of the $21^{\text {st }}$ century.

The key component or overall theoretical idea of what a capstone course should be is not difficult to find in the literature. For example, according to the APA (2008a), a key component of a capstone course is to provide psychology students the opportunity to apply their knowledge. As Dunlap (2005) and Stiggins (1997) both describe, a primary goal of teaching and outcomes assessment in the capstone course involves presenting students with authentic challenges connected with knowledge mastery, reasoning proficiency, and professional expectations. Wade (1997) states a capstone experience should help students "integrate, apply, and evaluate ... diverse findings as well as the psychological perspectives" (p. 151). Furthermore, Wagenaar (1993) concludes a capstone course should provide "a culminating experience in which students are expected to integrate, extend, critique, and apply the knowledge gained in the major" (p. 209). There are several ways to integrate these themes, pedagogical goals, and key ideas into a class; it could be through a practicum, Socratic discussion, or even a research project. This generalizability is strength of the capstone course along with its ability to allow an instructor to assess the student's overall collegiate learning experience and act as a method of summative evaluation. However, the lack of concrete recommendations on which pedagogical style to use in order to effectively teach a capstone course leaves psychology undergraduate students with an inconsistent and possibly ineffective or incomplete educational experience.

\section{Discussion as a Pedagogical Tool}

Whether the guidelines or key themes come from the APA, the Boyer Commis- 
sion on Educating Undergraduates, or other qualified experts on psychological education; the goal of undergraduate institutions becomes how can psychology undergraduate programs provide a consistently useful capstone course in which each recommendation is met. The possible solution for this dilemma is a discussion-based approach to the capstone course. A discussion-based approach would allow the flexibility needed for student differences in their base knowledge. Boonyaprakob (2002: p. 219) suggests that, "For a [teaching] program to foster students' developmental growth, the student should be considered not only as a learner but also as a developing person." This means that any capstone course must be malleable in regard to meeting students where they are intellectually. An example of this teaching challenge is given by Felder and Brent (2004: p. 276):

Students at Level 5 might flourish in a classroom environment based on cooperative and problem-based learning, in which the students are routinely confronted with high-level open-ended problems and are given guidance by the instructor when it is needed but are basically left to find their own way ... Level 2 students and many Level 3 students, on the other hand, might find such an environment uncomfortable enough to derail their learning.

Kloss (1994) argues that if students are pushed too hard to embrace complex ways of thinking they may begin to retreat rather than grow. As Kloss warns, "A nudge is better than a shove in these matters" or the teacher risks alienating the student (Kloss, 1994: p. 153). How can teachers skillfully nudge students into engaging with topics that become more complex (and often abstract) as their academic careers continue? One such method is the use of discussion groups as they can "help students to connect with and develop new ideas, wrestle with alternative perspectives, and apply new knowledge to complex problems in collaboration with their peers" (Jones, 2014: p. 13; see also Dallimore et al., 2004).

When teaching is interactive there can be dramatic learning outcomes. Freeman et al. (2014) recently conducted a meta-analysis of 225 studies which found that undergraduate classes with active learning components not only showed a $6 \%$ increase in exam scores, they showed more than a 50\% reduction in fail rates by students. Additionally, Jones (2014) found that group discussion was most effective when positive within-group functioning was present, which increased student outcomes such as critical thinking, application, and overall course satisfaction.

Furthermore, course topics themselves can often generate differing classroom engagement based upon how invested students are with the content. In particular, course topics that offer considerable substance and salience can initially elicit considerable affective responses that propel an engaged discussion during subsequent class sessions. Affective responses involve "emotions that arise during learning and lead to affective states that may positively, neutrally, or negatively influence the progress of a learning process" (Vermunt \& Vermetten, 2004: p. 361). Some examples would be exploring the consequences of being exposed to a 
hostile divorce between one's parents as a child (Donner, 2006), or mate-poaching (Schmitt, 2004) as these are pertinent topics across various genders, sexualities, ethnicities, races, and socioeconomic statuses. Additionally, with the diversity of college students growing, finding salient topics relevant to a superficially unalike group is now more important than ever (Espinosa et al., 2019). The ensuing discussions of these topics can further increase salience through the analytical exploration of these affective responses and influence the overall impact of the learning (Jones \& Bursens, 2015; Vermunt \& Vermetten, 2004). Bradley et al. (2008) called for additional research on the consequences of course discussion that is limited-focal (discussion centered on "opinions", for instance) compared with course-linked discussion (using direct reference to particular course materials).

Various discussion structures can facilitate or impede student response types and in turn, affect the achievability of particular learning goals (Bradley et al., 2008). Thus, as Evans and Witkosky (2007) argue, using discussion as a pedagogical tool requires discrimination and restraint; merely offering a supportive environment for students and then prompting them to discuss a topic is not enough to be considered a full-inquiry-based approach to education. The supportive approach is oversimplified and ignores a fundamental component of particular import; namely, the skillful use of questions. Research indicates that the type of questions asked influence the subsequent substance and extent of discussion produced (Bradley et al., 2008; Smith \& Higgins, 2006). For example, Andrews (1980) found that explicit fact-based questions ("What was the name of that institution?"), yield the lowest subsequent associated number of student statements (1.45), compared with a focal invitation to explore a topic ("Can we make any generalizations about the play as a whole, from the nature of the opening lines?"), which yields an average number of 5.08 subsequent related student statements.

Bradley et al. (2008) corroborate these findings and raise some highly relevant issues regarding mapping classroom discourse. Using a study of online discussion, based in part on the original work by Andrews (1980), Bradley et al. (2008) found that limited focal and direct link question types generated the most words, followed by the brainstorm and open focal questions. Application and course link question types generated the fewest words. Based upon those findings, Bradley et al. (2008) speculated that students refrained from answering these types of questions due to a dislike of the structure of the questions. Therefore, discussion can indeed be a useful pedagogical tool, but like any tool one needs to first learn how to use it in order to create the intended product.

\section{Socrates and the Art of Skillful Questioning}

Discussion within the classroom prompts synthesis and promotes the use of higher order aspects of knowledge use (Bloom, 1957). The process of skillful questioning involves not just eliciting answers from students, but in exercising 
the high-order thought processes of analysis, synthesis, and evaluation necessary for continuing success in future endeavors. As Reese (2005) explains, it is not just about finding questions but finding the right questions to open up the discussion process. In a time where there are many pedagogical techniques to choose from, educators can choose to revive the Socratic Method in spite of its increasing abatement, even in law schools where it is traditionally used (Kerr, 1999).

Socrates is widely considered the archetypal father of Western philosophical practices. He became renowned for his ability to use strategic questioning as a means of facilitating critical thought and self-generated knowledge. Over time, this method of pedagogy became known as Socratic questioning, which is best articulated by Paul (1995: p. 297).

This consists in teachers wondering aloud about the meaning and truth of students' responses to questions. The Socratic teacher models a reflective, analytic listener. One that actively pursues clarity of expression. One that actively looks for evidence and reasons. One that actively considers alternative points of view. One that actively tries to reconcile differences of viewpoint. One that actively tries to find out not just what people think but whether they think it is actually so.

This form of questioning facilitates a more open form of discussion where different viewpoints can be compared and contrasted with one another. Authentically demonstrating the process of asking ambiguous questions, carefully analyzing potential answers, and attempting to reconcile differing viewpoints, allows the instructor (or in this case, facilitator) to model the process of learning itself. It also replicates experiences that may be had within graduate schools or the workforce if the student were to continue to engage within the discipline.

The Socratic method can also encourage collaboration through establishing an expressive and supportive environment where constructive student group discussion is promoted (Burns, Stephenson, \& Bellamy, 2016; Kerr, 1999). This can be achieved by the facilitator modeling positive group dynamics, offering a speculative "nudge" in discourse when it is necessary, and sitting back and allowing student discourse when possible and appropriate (Jones, 2014). Tofade et al. (2013) have identified specific sequencing that can be useful for Socratic questioning by splitting questions into three categories:

1) Exploratory, where topics are introduced, past discussions are reviewed, and student's previous knowledge is assessed;

2) Spontaneous, where student perceptions are probed and reflected upon;

3) Focused, where students are presented with specific issues that they are encouraged to share their ideas.

As such, this nudges students toward analysis, synthesis and evaluation: the three key high-order components of Bloom's (1957) taxonomy. Largely, those who implement the Socratic method maintain that "only through this dialogue, entered into earnestly and honestly by both discussants, will a more accurate truth than held individually be discerned by both parties" and that students will 
develop their own intellectual journey at their discretion (Riffel, 2014: p. 127).

Previously, Bradley et al.'s (2008) findings were mentioned in regard to the salience of topics and their direct linkage to the way in which discussion was initiated. Another complexity they noted was that students appear to have a preference for enthusiastic tangential conversation rather than a sustained focus on the central aspect of a topic. This is particularly the case when the topic is proximal and/or counters long-held beliefs. This can unfortunately derail the discussion and potentially stray from the overall theme; which if this occurs, the discussion may no longer have the effect desired by the class or instructor. An example of this comes from our own capstone course where we found that the existential discussion of mortality salience, or the awareness of an individual that their death is inevitable and unavoidable (Pyszczynski, Greenberg, \& Solomon, 1999), is one such topic. Since the topic is angst-producing, without conscientious guidance the discussion may (or may appear to) veer "off topic." This is where, based on the Socratic method, the instructor acts as a mentor, allowing sufficient room for students to examine the topic within a framework that makes sense to them, while still gently tugging them back toward the major theme. Moore (2005) also recognizes the importance of this affective component in learning as it drives students to engage not only with their own thoughts, but also of those around them that may be wildly different from their own (this could include attitudes about race, sexuality, or other underserved and persecuted communities). This can result in a significant shift in students' pedagogical attitudes, specifically in beliefs that would normally be resistant to change.

However, skillful questioning of students is only half of the equation to inquiry-based education; the second half involves teaching students to generate their own questions about the topic. Rosenshine, Meister and Chapman (1996) explored intervention studies where students had been asked to generate questions about material they had read. The process of generating questions prompted students to engage actively with the material while at the same time giving the instructor a method by which the students' overall understanding of the subject could be assessed. The results demonstrated that students who had been taught to generate questions on the topic themselves had higher levels of comprehension than those who had not been taught by this method. Rosenshine et al. (1996: p. 182) describe this as:

a guide that serves to support learners as they develop internal procedures that enable them to perform higher-level operations. Generating questions about material that is read is an example of a cognitive strategy. Generating questions does not lead directly, in a step-by-step manner, to comprehension. Rather, in the process of generating questions, students need to search the text and combine information, and these processes help students comprehend what they read.

The Socratic method relies on preparation as it draws from previous knowledge and experience; if a student doesn't actively engage with the material and 
comprehend it, they will be unable to effectively participate in the discussion (Riffel, 2014). Consequently, having students generate their own questions in order to increase their comprehension should facilitate the actual Socratic discussion. This is also congruous with Vygotsky's scaffolded-learning technique. Students are being taught a strategy to deal with ill-structured tasks and develop meaning from the information given to them.

This highlights the strength of the Socratic method in terms of its malleability as a pedagogical practice: it not only meets students where they are conceptually, it also fosters learning through both scaffolding processes and by actively engaging students with development of their conceptual understanding in terms that are authentic to them. Teachers must not only ask the right questions but also be skilled in guiding students to ask their own questions about the topic. They must also incorporate scaffolded-learning techniques and be aware that students enter the discourse with different levels of intellectual development which need to be carefully monitored in order to avoid alienating students and subsequently stunting their growth. Unfortunately, accomplishing many of these tasks is difficult in a large class, as even Socrates seemed to only use his methods with limited numbers of interlocutors at a time. To speak up, or be cold-called on, is a frightening experience for many, even in welcoming and familiar situations. An increase in class size could escalate the likelihood of the environment feeling hostile, thus a lecture hall with an immoderate number of students seems ill-disposed for creating a place to question one's established truths (Riffel, 2014).

\section{Socratic Teaching in a Capstone Course}

The corresponding author's capstone course is based on the Constructivist Learning Environment model (CLE) designed by Jonassen (2002) with the objective to foster a classroom atmosphere where students are actively involved in dealing with ill-structured, real-life issues. Essenhigh (2000) states that the goal of the capstone experience should be to teach students not just the facts, but to train them in regard to thinking their own thoughts and deriving meaning from them.

The corresponding author uses teaching modeled after the Socratic method, with the course being fully discussion-based; this course can be used as an example to demonstrate how a capstone course may be taught using the suggestions made within this paper. In the corresponding author's course, weekly topics are selected in an effort to foster as well as challenge, students' preexisting knowledge and perspectives that have been acquired in prior courses. As students review several selected readings within the topic, they can experience alternative (and sometimes conflicting) perspectives. Students are asked to submit questions that they had while surveying the readings, which can be used as a foundation for framing discussions based upon differing perspectives and interpretations, as well as developing alternative ways of resolving the different van- 
tage points. While students' questions often reflect reactive themes to assigned readings, this initial reaction is an integral component of the course, as are gauging the reactions of others, processing affective components of oneself and others, and providing feedback on raised viewpoints within the topic at hand. All of this works in tandem to drive the learning of the entire classroom as questions are addressed through successive discussion and further inquiry.

Jonassen (2002) asserts that it is within this context of co-operative problem solving that allows the facilitator to guide and scaffold their students. This scaffolding can be achieved readily by the facilitator modeling response-based inquiries regarding students' questions, modeling reasoning strategies in response to raised questions, and providing related experiences about which students may not have first-hand experience. For example, one section of the course is on the topic of loss and grief, and initially many students respond to the topic by claiming that they have not "lost" anyone, appearing to believe "loss" is exclusively related to death. However, when the discussion shifts away from death-related losses to relationship break-ups, and then circles back to the empirical work related to this, students are often able to connect effectively with the topic (Wortman \& Silver, 1989). This approach assures a higher degree of salience for students' understanding of a topic, as students are encouraged to explicate upon these topics by utilizing their own comprehensive techniques rather than being purely reliant upon the rationalization of the lecturer.

The goal of this Socratic teaching method is to accomplish each of the guidelines identified by the APA (2007). In particular, to encourage capstone students to value the effort required of them to engage in genuine critical thinking (rather than simply being critical), to provide them with a wealth of opportunities so they may apply the sum of their acquired skills and knowledge, as well as to bring it to bear on authentic contemporary issues (e.g., parenting, interpersonal relationships, culture, diversity, etc.). In this way, students learn to tolerate ambiguity while reflecting on their personal and adopted discipline-based ethics along with professional values; all of which satisfies the major goals and guidelines produced by the APA.

This brings us to the importance of meaning-making within psychology. Krauss explained, "The complexity of meaning in the lives of people has much to do with how meaning is attributed to different objects, people and life events" (Krauss, 2005: p. 763). So, the priority of the capstone course should be upon melding these personal variances in meaning, along with different psychological theories found within the discipline. By incorporating meaning-making, a course lends itself to become an effective learning experience that prepares undergraduates for further exploration within psychology as well as real-world application within their career (APA, 2016).

Perry's full learning model (1970) posits nine stages of intellectual development starting with basic duality (where knowledge is essentially "right" or "wrong") and culminating in the ninth stage of development: commitment. The 
aim of college education should be to guide students towards Perry's ninth stage, where students will understand that the better part of knowledge is relative instead of absolute. Utilizing their sense of personal identity and experience, they should be able to critically assess the multitude of view-points for each theory and have the capacity to validate their own position on the topic at hand by taking an honest and committed stand despite any lingering sense ambiguity or conflicting sources (Thomas, 2008). Lectures are useful in that they are able to communicate factual information to large audiences where there is an intellectual gap between the speaker and the audience (Charlton, 2006). However, as Felder and Brent (2004) argue, students are not being given the opportunity to view science as a process of inquiry as lectures are experienced as the passive absorption of presumably true knowledge via the instructor and is not conducive to investigation or meaning-making (Jones \& Bursens, 2015). Thus, another primary goal of a capstone course should be to provide students with several opportunities to integrate, analyze, and evaluate the various theories and practices. This inquiry-based teaching will equip students with a properly-cemented foundation of understanding that is conducive to further exploration of the field.

Cuseo's (2007) review of undergraduate teaching methods draws out key findings regarding the negative impact of large class sizes: in particular, they,

1) Reduce the students' active involvement in the learning process;

2) Reduce the frequency and quality of teacher interaction and feedback;

3) Reduce the students' level of cognitive activity;

4) Limit the breadth and depth of course objectives, assignments and course related learning;

5) Lower students' academic achievement and performance.

Moreover, it has been found that disadvantaged students, such as women and underserved minority populations (African American, Native American, Hispanic, etc.), suffer the greatest negative impact from large classes (Ballen et al., 2018; Diette \& Raghav, 2015). Concurrently, students report lower levels of satisfaction and give lower ratings to courses that are delivered in large classes (Cuseo, 2007; Jones, 2014). Finally, students in large classes display a limited engagement with their courses and may not develop critical thinking skills that are essential for real-life application outside of the classroom (Cuseo, 2007).

Some may argue that since the majority of students will progress to the end of the course, a change in teaching methods is unnecessary. However, Halpern et al. (2010) cite evidence from universities in the United States suggesting that few psychology students are choosing to continue their education at the graduate level. According to Conroy et al. (2019), about 56\% of those who held bachelor's degrees in psychology did not go on to earn graduate degrees. The APA (2008b) explains that "opportunities in psychology for those with graduate degrees will be more plentiful and at a higher level than for those with undergraduate degrees" (p. 2) as it has consistently been over time; thus, pursuing a graduate degree will foster more opportunity within the psychology field. As determined by 
Mullen, Goyette, and Soares (2003), the biggest impact on whether a student continues to graduate school appears to be based upon their experiences and success in their undergraduate education. Thus, a lack of concrete integrative teaching methods and limited engagement may explain why students fail to progress (Belanger, Dills, Hernandez-Julián, \& Rotthoff, 2017; Dooris, 2002). As student ratios grow and classes become more lecture-heavy, teachers are left without the means to provide optimal integrative experiences for their students, leading to a lower quality of student interaction with the material.

This means that while psychology students may make some epistemological progress during their time in college, the majority are at risk of graduating with diminished interest and without having well developed meaning-making strategies that are essential for the recognition and comprehension of knowledge as a social construct (Pizzolato, 2006). Yet the American Psychological Association's (APA 2002, 2007, 2013) guidelines emphasize that the explicit goals of a psychology major include critical and creative thinking and the ability to apply psychological principles to personal, social and organizational issues. In addition, students should learn how to evaluate psychological theories in terms of design and effectiveness and demonstrate the capacity for generating potential solutions to problems.

It should be clearly noted that this review is not intended to discredit lecture-based teaching. There can be no doubt that lectures have merit (Gold, 1991), but lecture-based teaching should be used in conjunction with other curricular options. Previously, Dunn et al. (2009) offered their proposal for concrete curricular recommendations in psychology that included four specific groups of courses: an introductory course, a methodology course, a content course, and integrative experiences that include either internships, research projects, or a capstone course. However, higher education institutions have generally ignored attempts to implement these guidelines (Dunn et al., 2009). If implementing any sort of synergistic courses, most institutions are turning to flipped classrooms, which are defined as having traditional lectures occur outside of class and having in-class time focus on completing projects or interactive assignments instead (Roehling et al., 2017). Despite their increasing popularity, there is not a significant amount of research to support the efficacy of a flipped classroom in a psychology course, where unlike STEM courses (which have significant coverage within the literature), they do not easily lend themselves to interactive material or practice (Roehling et al., 2017). In addition, Halpern et al. (2010) reported that rather than providing a solid undergraduate curriculum, psychology departments have exhibited a growing trend of delivering specialized courses. Whilst not inherently negative, this specialization risks fragmentation within the discipline; a matter that runs parallel to the call of Brewer et al. (1993) for delivering core experiences within psychology curriculum.

Finally, the aim of psychology departments should emphasize not only retaining students within and beyond undergraduate study, but also in preparing 
them for jobs within the field (APA, 2016: p. 110). However, if students are not engaging in the course material, nor being offered integrative teaching, such as through a capstone course, how can they be expected to synthesize and deliver these skills later on in their careers?

\section{Meaning-Making through Inquiry-Based Teaching}

Bloom's taxonomy (1957) was an extension and elaboration of cognitive principles initially introduced by the APA. Bloom's multi-tiered model was formed in order to aid in developing epistemological learning objectives by recognizing the processes of learning as existing on a continuum, with analysis, synthesis, and evaluation as its highest three levels (see also Anderson \& Krathwohl, 2001). These three highest levels of cognitive processing highlight the requisite need to comprehend constituent parts of a problem and to link disparate sources or perspectives in order to form a coherent and functional whole or, more simply, meaning-making.

Meaning-making is the ability to see the differences around us, and then form them into some sort of order that makes coherent sense (Ignelzi, 2000; Kegan, 1983; Krauss, 2005). It has two fundamental aspects: intellectual maturity and situations that encourage autonomous problem-solving (Clegg, 2015; Huber \& Hutchings, 2005; Pizzolato, 2006). Inquiry-based teaching methods, where a teacher poses a question and then prompts students to actively participate in analyzing data and drawing conclusions, afford teachers the ability to actively model strategies related to knowledge formulation within the context of task completion. Equipping students with the intellectual capacity to tolerate ambiguity in meaning is incredibly important in comprehending psychology as an evolving discipline and assists in maneuvering students' thought processes from a dualistic worldview towards more multiplistic or relativistic models of thought (APA, 2016; Perry, 1970).

One strength of inquiry-based teaching methods is that students of differing abilities can easily be accommodated due to the malleability of its design. Teachers can meet students where they are intellectually and foster individual growth as needed until they are able to fully synthesize and evaluate the topic at hand. As discussed by Kegan (1983), one must construct a bridge between the student's current understanding and that of the new understanding, so that they may cross over it. This follows Vygotsky's (1978) concept of scaffolded instruction whereby the teacher carries out the task in a meaningful context. The students are then asked to join in with the task with the eventual goal being that they learn how to carry the task out independently (Wilhem, Baker, \& Dube, 2001). Thus, the teacher provides the scaffolding for the student's learning experience until the student has all the necessary building blocks for a particular strategy at which point the scaffold of the teacher support can be removed. In an empirical study, Jones and Maxwell (2007) compared second-year students from a Bachelor of Education degree program. They examined the students' scaf- 
folded and unscaffolded reflective writings on two administrations of student learner self-efficacy scales. The use of scaffolded teaching resulted in deeper knowledge and understanding of the subject in comparison with unscaffolded teaching. Scaffolded students were more engaged with the subject and were more willing to use their own experiences and link them with their new knowledge to form new understanding.

Another strength of inquiry-based teaching is that it fosters an application-based approach to knowledge. Ge and Land (2003) cite the importance of teaching students not only to learn problem solving skills but also to be able to transfer these skills from one context to another. Utilizing inquiry-based methods, students get to practice using critical thinking skills by assessing a particular topic and offering their insight, thereby acting as co-facilitators of their own learning. Lecture-based teaching, in contrast, does not typically provide this same opportunity for students to engage with meaning-making or to apply these skills to everyday problem-solving. Summarized differently, inquiry-based learning provides the opportunity for learning the content of the discipline but also for application of techniques used by the discipline (Abd-El-Khalick et al., 2004). Meta-analyses have supported these notions by revealing that inquiry-based teaching methods are more effective in helping students' conceptual understanding of topics and facilitate greater student achievement overall (Balta \& Sarac, 2016; Lazonder \& Harmsen, 2016; Minner et al., 2010).

\section{How to Assess Integrative Learning}

It could be argued that capstone courses based upon inquiry-based teaching methods lack the capacity for accurately monitoring and assessing student progress. Moore (2005) takes the stance that the capstone course itself is a form of direct assessment: "It not only assesses previous cognitive learning in the major, but also provides a forum that allows an instructor to assesses the student's overall collegiate learning experience" (Moore, 2005: p. 440). Furthermore, Moore stresses the importance of evaluation as it provides students with the critical validation of their own learning progress. Additionally, while the APA (2007) may suggest the inclusion of a capstone experience in the curriculum there is no clear guidance on how the learning outcomes should be monitored, other than by the general inclusion of examinations. Monitoring student progress through examinations is one method of ascertaining what the student has learnt. However, it cannot indicate how successfully the student can apply this knowledge to real-life problems or provide an assessment of the student's intellectual development as students enter a capstone course at different intellectual levels and, more importantly, with different learning styles (Felder \& Brent, 2005).

A capstone course must, therefore, provide empirical evidence that students actually benefit from the experience and achieve the intellectual outcomes recommended by the APA. Some colleges culminate a capstone with a student 
project, others ask students to form a written portfolio of work that demonstrates their collegiate learning experience (Perlman \& McCann, 1999). According to Huber and Hutchings (2004), the use of writing as an assessment measure provides a reliable and valid insight into one's thinking, with a few guidelines: primarily a clear statement of what one proposes to assess and the use of a scoring rubric which, to be fair and valid, should be made public to the students. Valid assessment requires careful consideration of the whole: purpose, scope, and method. For example, Burns, Stephenson and Bellamy (2016) used the Learning Environment Preference instrument (LEP) (Moore, 1989) to assess 135 students' epistemological development in a series of separate 15-week capstone courses. Through the LEP measurements the study found that a capstone course, based on the Socratic teaching method, enabled students to demonstrate the ability to tolerate ambiguity and to challenge preconceived beliefs through the use of open discussion and scaffolded-learning, in contrast with the lecture-only control group.

This is not to say established assessment models should be displaced, as examinations and academic assessment are still integral parts of a capstone course. However, within a capstone there is also a need to assess the balancing act of teaching style with student learning outcomes and cognitive development and to adjust the teaching style accordingly.

\section{Conclusion}

While lecture-based courses can serve to deliver information to more students in a cost-effective manner, often they do not offer the same degree of intellectual development as smaller classes using integrative and inquiry-based learning methods.

This review is not suggesting an end to lectures, rather than implementing inquiry-based teaching, where appropriate and feasible, remains a strategy that is currently being undervalued by many within academia. The failure to promote integrative learning practices denies students the opportunity to explore meaning-making, attain greater educational outcomes, and to rise in their intellectual development. Furthermore, Bain (2004: p. 134) laments the demise of Socratic teaching by arguing that:

Great teachers are not just great speakers or discussion leaders; they are, more fundamentally, special kinds of scholars and thinkers, leading intellectual lives that focus on learning, both theirs and their students'. They focus on the nature and process of learning, rather than the performance of the instructor.

These ideas must be encompassed in a psychology capstone experience and it is here that the APA should take the lead in guiding colleges on not just what should be taught in psychology, but how it should be taught.

Strategies related to integrative pedagogical approaches continue to show improved learning outcomes for students. Moreover, the unique nature of psychology as an evolving discipline requires an integrative approach by its very 
nature, as the skills necessary for exploring and challenging meaning cannot be reliably delivered from a lecture podium. Psychology is itself an inquiry-based practice, and teaching methods should seek to mirror this agenda. It is not enough for students to take a passive role in traversing obtuse topics; they must practice the skills related to conversing with others, navigating alternate opinions, digging into concepts, and formulating their own opinions, all of which are vital for both therapeutic practice and research-based careers in psychology. Socratic-based capstone classes, where students are committed to a discipline and eager to learn, could be powerful in teaching meaning-making and moving students to a deeper understanding of material. By gaining critical insight, students are allowed to fully realize their own capabilities, ultimately permitting them to push their discipline in new directions by utilizing skillful questioning strategies and applying their acquired knowledge.

\section{Conflicts of Interest}

The authors declare no conflicts of interest regarding the publication of this paper.

\section{References}

Abd-El-Khalick, F., BouJaoude, S., Duschl, R., Lederman, N. G., Mamlok-Naaman, R., Hofstein, A., Tuan, H. et al. (2004). Inquiry in Science Education: International Perspectives. Science Education, 88, 397-419. https://doi.org/10.1002/sce.10118

Anderson, L. W., \& Krathwohl, D. R. (2001). A Taxonomy for Learning, Teaching and Assessing: A Revision of Bloom's Taxonomy of Educational Objectives: Complete Edition. New York: Longman.

Andrews, J. D. W. (1980). The Verbal Structure of Teacher Questions: Its Impact on Class Discussion. POD Quarterly, 2, 129-163.

APA (American Psychological Association) (2011). Principles for Quality Undergraduate Education in Psychology. Washington, DC: Author.

https://www.apa.org/education/undergrad/principles

APA American Psychological Association (2005). Profiles of Undergraduate Programs in Psychology. https://www.apa.org/education/undergrad/profiles

APA American Psychological Association (2007). APA Guidelines for the Undergraduate Psychology Major. Washington DC: American Psychological Association. http://www.apa.org/ed/precollege/about/psymajor-guidelines.pdf

APA American Psychological Association (2008a). National Conference on Undergraduate Education in Psychology. The 2nd Annual Great Plains Conference on the Teaching of Psychology, Vermillion, 17-18 October 2008, 1-6.

APA American Psychological Association (2008b). Psychology Careers Guide. http://www.apa.org/careers/resources/guides/careers

APA American Psychological Association (2013). APA Guidelines for the Undergraduate Psychology Major Version 2.0. Washington DC: APA. http://www.apa.org/ed/precollege/about/psymajor-guidelines.pdf

APA American Psychological Association (2016). Guidelines for the Undergraduate Psychology Major: Version 2.0. The American Psychologist, 71, 102-111.

https://doi.org/10.1037/a0037562 
APA American Psychological Association, Task Force on Undergraduate Psychology Major Competencies (2002). Undergraduate Psychology Major Learning Goals and Outcomes: A Report. Washington DC: American Psychological Association.

Bain, K. (2004). What the Best College Teachers Do. Cambridge, MA: Harvard University Press.

Ballen, C. J., Aguillon, S. M., Brunelli, R., Drake, A. G., Wassenberg, D., Weiss, S. L., Zamudio, K. R., \& Cotner, S. (2018). Do Small Classes in Higher Education Reduce Performance Gaps in STEM? BioScience, 68, 593-600. https://doi.org/10.1093/biosci/biy056

Balta, N., \& Sarac, H. (2016). The Effect of 7E Learning Cycle on Learning in Science Teaching: A Meta-Analysis Study. European Journal of Educational Research, 5, 61-72. https://doi.org/10.12973/eu-jer.5.2.61

Behrens, P. J. (2005). Bringing Closure to the Major in Psychology: The Capstone Course for Seniors. The Teaching of Psychology: Ideas and Innovations Conference, Proceedings of the 19th Annual Conference on Undergraduate Teaching of Psychology, Monticello, NY, 6-8 April 2005, 1-58.

Belanger, K. P., Dills, A. K., Hernandez-Julián, R., \& Rotthoff, K. W. (2017). Class Size, Learning, and Knowledge Decay. https://doi.org/10.2139/ssrn.2928459

Bloom, B. (1957). Taxonomy of Educational Objectives. New York: McKay.

Boonyaprakob, K. (2002). A Comparative Analysis of Longitudinal Studies of College Students' Intellectual Development. Unpublished Doctoral Thesis, Raleigh, NC: NCSU Digital Repository, North Carolina State University.

http://www.lib.ncsu.edu/resolver/1840.16/4491

Boyer Commission on Educating Undergraduates (1998). Reinventing Undergraduate Education: A Blueprint for American Research Universities. Stony Brook, NY: State University of New York. http://files.eric.ed.gov/fulltext/ED424840.pdf

Bradley, M. E., Thom, L. R., Hayes, J., \& Hay, C. (2008). Ask and You Will Receive: How Question Type Influences Quantity and Quality of Online Discussions. British Journal of Educational Technology, 39, 888-900. https://doi.org/10.1111/j.1467-8535.2007.00804.x

Brewer, C. L., Hopkins, J. R., Kimble, G. A., Matlin, M. W., McCann, L. I., McNeil, O. V., Nodine, B. F., Quinn, V. N., \& Saundra (1993). Curriculum. In T. V. McGovern (Ed.), Handbook for Enhancing Undergraduate Education in Psychology (pp. 161-182). Washington DC: American Psychological Association. https://doi.org/10.1037/10126-006

Burns, L. R., Stephenson, P. L., \& Bellamy, K. (2016). The Socratic Method: Empirical Assessment of a Psychology Capstone Course. Psychology Learning \& Teaching, 15, 370-383. https://doi.org/10.1177/1475725716671824

Charlton, B. G. (2006). Lectures Are Such an Effective Teaching Method Because They Exploit Evolved Human Psychology to Improve Learning. Medical Hypotheses, 67, 1261-1265. https://doi.org/10.1016/j.mehy.2006.08.001

Clegg, S. (2015). Adventures in Meaning Making: Teaching in Higher Education 2005-2013. Teaching in Higher Education, 20, 373-387. https://doi.org/10.1080/13562517.2015.1020781

Conroy, J., Christidis, P., Fleischmann, M., \& Lin, L. (2019). Datapoint: How Many Psychology Majors Go on to Graduate School? Monitor on Psychology, 50, 19. http://www.apa.org/monitor/2019/09/datapoint-grad-school

Cuseo, J. (2007). The Empirical Case against Large Class Size: Adverse Effects on the Teaching, Learning, and Retention of First-Year-Students. Journal of Faculty Devel- 
opment, 21, 5-22.

Dallimore, E. J., Hertenstein, J. H., \& Platt, M. B. (2004). Classroom Participation and Discussion Effectiveness: Student-Generated Strategies. Communication Education, 53, 103-115. https://doi.org/10.1080/0363452032000135805

Diette, T. M., \& Raghav, M. (2015). Class Size Matters: Heterogeneous Effects of Larger Classes on College Students Learning. Eastern Economic Journal, 41, 273-283. https://doi.org/10.1057/eej.2014.31

Donner, M. B. (2006). Tearing the Child Apart. Psychoanalytic Psychology, 23, 542-553. https://doi.org/10.1037/0736-9735.23.3.542

Dooris, M. J. (2002). Working with Your IR Officer. First-Year Assessment (FYA) Listserv Series. http://www.brevard.edu/fyc/listserv

Dunlap, J. C. (2005). Problem-Based Learning and Self-Efficacy: How a Capstone Course Prepares Students for a Profession. Educational Technology Research and Development, 53, 65-85. https://doi.org/10.1007/BF02504858

Dunn, D. S., Brewer, C. L., Cautin, R. L., Gurung, R. A. R., Keith, K. D., McGregor, L. N., Nida, S. A., Puccio, P., \& Voigt, M. J. (2009). The Undergraduate Psychology Curriculum: Call for a Core. In D. F. Halpern (Ed.), Undergraduate Education in Psychology (pp. 47-61). Washington DC: American Psychological Association. https://doi.org/10.1037/12063-003

Espinosa, L. L., Turk, J. M., Taylor, M., \& Chessman, H. M. (2019). Race and Ethnicity in Higher Education: A Status Report. Washington DC: American Council on Education.

Essenhigh, R. H. (2000). A Few Thoughts on the Difference between Education and Training. National Forum: The Phi Kappa Phi Journal, Spring, 46.

Evans, R. C., \& Witkosky, D. V. (2007). Socrates Updated: Using the Socratic Method to Foster Scholarly Publication by Students. National Social Sciences Journal, 28, 33-41.

Felder, R. M., \& Brent, R. (2004). The Intellectual Development of Science and Engineering Students Part 1. Models and Challenges. Journal of Engineering Education, 93, 269-277. https://doi.org/10.1002/j.2168-9830.2004.tb00816.x

Felder, R. M., \& Brent, R. (2005). Understanding Student Differences. Journal of Engineering Education, 94, 57-72. https://doi.org/10.1002/j.2168-9830.2005.tb00829.x

Freeman, S., Eddy, S.L., McDonough, M., Smith, M. K., Okoroafor, N., Jordt, H., \& Wenderoth, M. P. (2014). Active Learning Increases Student Performance in Science, Engineering, and Mathematics. Proceedings of the National Academy of Sciences, 111, 8410-8415. https://doi.org/10.1073/pnas.1319030111

Ge, X., \& Land, S. M. (2003). Scaffolding Students' Problem-Solving Processes in an Ill-Structured Task Using Question Prompts and Peer Interactions. Educational Technology Research and Development, 51, 21-38. https://doi.org/10.1007/BF02504515

Gold, J. R., Jenkins, A., Lee, R., Monk, J., Riley, J., Shepherd, I., \& Unwin, D. (1991). The Lecture. In Teaching Geography in Higher Education. A Manual of Good Practice. Oxford: Blackwell.

Halpern, D. F., Anton, B., Beins, B. C., Bernstien, D. J., Blair-Broeker, C. T., Brewer, C. L., Buskist, W., Casad, B. J., Dixon Jr., W. E., Harper, Y. Y., Hailstorks, R., Kite, M. E., Puccio, P., \& Rocheleau, C. A. (2010). Principles for Quality Undergraduate Education in Psychology. In D. F. Halpern (Ed.), Undergraduate Education in Psychology: A Blueprint for the Future of the Discipline (pp. 161-173). Washington DC: American Psychological Association. https://doi.org/10.1037/12063-010

Huber, M. T., \& Hutchings, P. (2004). Integrative Learning: Mapping the Terrain. Washington DC: The Carnegie Foundation for the Advancement of Teaching, Association of 
American Colleges and Universities.

Huber, M. T., \& Hutchings, P. (2005). The Advancement of Learning: Building the Teaching Commons. San Francisco, CA: Jossey-Bass.

Ignelzi, M. (2000). Meaning-Making in the Learning and Teaching Process. New Directions for Teaching and Learning, No. 82, 5-14. https://doi.org/10.1002/tl.8201

Jonassen, D. H. (2002). Engaging and Supporting Problem Solving in Online Learning. Quarterly Review of Distance Education, 3, 1-13.

Jones, J. M. (2014). Discussion Group Effectiveness Is Related to Critical Thinking through Interest and Engagement. Psychology Learning and Teaching, 13, 12-24. https://doi.org/10.2304/plat.2014.13.1.12

Jones, M. A., \& Maxwell, T. W. (2007). Scaffolded and Unscaffolded Reflection on Bachelor of Education Students' Learner Self-Efficacy. https://rune.une.edu.au/web/bitstream/1959.11/4040/4/open/SOURCE02.pdf

Jones, R., \& Bursens, P. (2015). The Effects of Active Learning Environments: How Simulations Trigger Affective Learning. European Political Science: EPS, 14, 254-265. https://doi.org/10.1057/eps.2015.22

Kegan, R. (1983). The Evolving Self: Problem and Process in Human Development. https://ebookcentral-proquest-com.ezproxy.gvsu.edu

Kerr, O. S. (1999). The Decline of the Socratic Method at Harvard. Nebraska Law Review, $78,113$.

Kloss, R. J. (1994). A Nudge Is Best: Helping Students through the Perry Scheme of Intellectual Development. College Teaching, 42, 151-158.

https://doi.org/10.1080/87567555.1994.9926847

Krauss, S. E. (2005). Research Paradigms and Meaning Making: A Primer. The Qualitative Report, 10, 758-770.

Lazonder, A. W., \& Harmsen, R. (2016). Meta-Analysis of Inquiry-Based Learning: Effects of Guidance. Review of Educational Research, 86, 681-718. https://doi.org/10.3102/0034654315627366

Minner, D., Levy, A., \& Century, J. (2010). Inquiry-Based Science Instruction-What Is It and Does It Matter? Results from a Research Synthesis Years 1984 to 2002. Journal of Research in Science Teaching, 47, 474-496. https://doi.org/10.1002/tea.20347

Moore, R. C. (2005). The Capstone Course. In W. G. Christ (Ed.), Assessing Media Education: A Resource for Educators and Administrators (pp. 439-459). Hillsdale, NJ: Erlbaum.

Moore, W. S. (1989). The Learning Environment Preferences: Exploring the Construct Validity of an Objective Measure of the Perry Scheme of Intellectual Development. Journal of College Student Development, 30, 504-514.

Mullen, A. L., Goyette, K. A., \& Soares, J. A. (2003). Who Goes to Graduate School? Social and Academic Correlates of Educational Continuation after College. Sociology of Education, 76, 143-169. https://doi.org/10.2307/3090274

Paul, R. (1995). Critical Thinking: How to Prepare Students for a Rapidly Changing World. Santa Rosa, CA: Foundation for Critical Thinking.

Perlman, B., \& McCann, L. I. (1999). The Structure of the Psychology Undergraduate Curriculum. Teaching of Psychology, 26, 171-176. https://doi.org/10.1207/S15328023TOP260302

Perry, W. G. (1970). Forms of Intellectual and Ethical Development in the College Years: A Scheme. San Francisco, CA: Jossey-Bass.

Pizzolato, J. E. (2006). Complex Partnerships. Self-Authorship and Provocative Academic-Advising Practices. NACADA Journal, 26, 32-45. 


\section{https://doi.org/10.12930/0271-9517-26.1.32}

Pyszczynski, T., Greenberg, J., \& Solomon, S. (1999). A Dual-Process Model of Defense against Conscious and Unconscious Death-Related Thoughts: An Extension of Terror Management Theory. Psychological Review, 106, 835-845.

https://doi.org/10.1037/0033-295X.106.4.835

Reese, J. (2005). Finding the Discussion Question That Works. The Teaching Professor, March, 3.

Riffel, C. (2014). The Socratic Method Reloaded: How to Make It Work in Large Classes? Canterbury Law Review, 20, 125-135.

Roehling, P. V., Root Luna, L. M., Richie, F. J., \& Shaughnessy, J. J. (2017). The Benefits, Drawbacks, and Challenges of Using the Flipped Classroom in an Introduction to Psychology Course. Teaching of Psychology, 44, 183-192.

https://doi.org/10.1177/0098628317711282

Rosenshine, B., Meister, C., \& Chapman, S. (1996). Teaching Students to Generate Questions: A Review of the Intervention Studies. Review of Educational Research, 66, 181-221. https://doi.org/10.3102/00346543066002181

Schmitt, D. P. (2004). Patterns and Universals of Mate Poaching across 53 Nations: The Effects of Sex, Culture, and Personality on Romantically Attracting Another Person's Partner. Journal of Personality and Social Psychology, 86, 560-584. https://doi.org/10.1037/0022-3514.86.4.560

Smith, H., \& Higgins, S. (2006). Opening Classroom Interaction: The Importance of Feedback. Cambridge Journal of Education, 36, 485-502. https://doi.org/10.1080/03057640601048357

Stiggins, R. J. (1997). Student-Centered Classroom Assessment (2nd ed.). Upper Saddle River, NJ: Prentice Hall.

Thomas, J. (2008). Reviving Perry: An Analysis of Epistemological Change by Gender and Ethnicity among Gifted High School Students. Gifted Child Quarterly, 52, 87-98. https://doi.org/10.1177/0016986207311422

Tofade, T., Elsner, J., \& Haines, S. T. (2013). Best Practice Strategies for Effective Use of Questions as a Teaching Tool. American Journal of Pharmaceutical Education, 77, 155. https://doi.org/10.5688/ajpe777155

Vermunt, J. D., \& Vermetten, Y. J. (2004). Patterns in Student Learning: Relationships between Learning Strategies, Conceptions of Learning, and Learning Orientations. Educational Psychology Review, 16, 359-384.

https://doi.org/10.1007/s10648-004-0005-y

Vygotsky, L. S. (1978). Mind in Society. Cambridge, MA: Harvard University Press.

Wade, C. E. (1997). On Thinking Critically about Introductory Psychology. In R. J. Sternberg (Ed.), Teaching Introductory Psychology: Survival Tips from the Experts (pp. 151-162). Washington DC: American Psychological Association.

https://doi.org/10.1037/10228-010

Wagenaar, T. C. (1993). The Capstone Course. Teaching Sociology, 21, 209-214. https://doi.org/10.2307/1319011

Wilhem, J., Baker, T., \& Dube, J. (2001). Strategic Reading: Guiding Students to Lifelong Literacy. NH: Heinemann

Wortman, C. B., \& Silver, R. C. (1989). The Myths of Coping with Loss. Journal of Consulting and Clinical Psychology, 57, 349-357.

https://doi.org/10.1037/0022-006X.57.3.349 